\title{
ノコンギク族植物の染色体分析
}

藤原 悠 紀 雄

神厂大学教養部生物学教空

Received November 30, 1964

\section{CHROMOSOME ANALYSIS IN THE TRIBE ASTEREAE.}

\section{YUKIO HUZIWARA}

Biological Institute, College of General Education, Kobe University, Nada, Kobe

\section{Résumé}

The chromosome numbers and the karyotypes of 11 species and 4 varieties belonging to 6 genera of the tribe Astereae of Compositae are reported. These are: Felicia bergeriana O. Hoffin, $2 n=18$; Erigeron speciosus DC., $2 n=18$; Solidago minutissima (Makino) Kitamura, $2 n=18 ; B o l$ tonia asteroides L'Her., $2 n=27$; Rhynchospermum verticillatum Reinw., $2 n=18$; Aster taiwanensis var. lucens Kitamura $2 n=18$; A. ageratoides subsp. leiophyllus var. ovalifolius Kitamura, $2 n=54$; A. sohayakiensis Koidzumi, $2 n=18$; A. rugulosus var. shibukawaensis Kitamura et Murata, $2 n=18$; A. dubius subsp. glabratus var. heterotrichus Kitamura, $2 n=18 ; A$. asperulus Nees, $2 n=54 ; A$. spinosus Benth., $2 n=18$; A. oregonensis (Nutt.) Cronq., $2 n=18$; A. bernardinus Hall, $2 n=36 ; A$. ontarionis Wieg., $2 n=40$.

キク科植物のうちノコンギク族 Astereae はアキノキリンソウ亜族 Solidaginae, シュウブンソウ亜族 Bellidinae, ノコンギク亜族 Asterinae, ワタナ亜族 Conyzinae などを含み, 種類が多く, 変化富む. 筆者（藤 原, 1941, 1954, 1957; Huziwara, $1957 \mathrm{a}, 1957 \mathrm{~b}, 1958 \mathrm{a}, 1958 \mathrm{~b}, 1958 \mathrm{c}, 1962 \mathrm{a}, 1962 \mathrm{~b}, 1962 \mathrm{c})$ は既に本 族植物のうち 9 属, 77 種, 20 亜種, 14 変種わよび 1 品種合計 112 種類について染色体数わよび核型を叝告した。 今回新たに11種および 4 変種について観祭を行なったので報告し, 既報の種と合わせ考察する.

材料および方法：染色体の観察はすべて根端細胞を用いて行ない，T Tio および Levan (1950)のオキシキ，

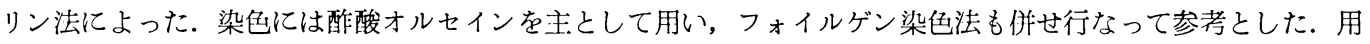
いた材料は次の通りである.

Felicia bergeriana O. Hoffin ルリヒナギク $2 n=18$

Erigeron speciosus DC. ヒロハヒメジョオン $2 n=18$

Soildago minutissima (Makino) Kitamura イッスンキンカ $2 n=18$

Boltonia asteroides L'Her. アメリカギク $2 n=27$

Rhynchospermum verticillatum Reinw. シュウブンソウ $2 n=18$

Aster taiwanensis var. lucens Kitamura テリハノギク $2 n=18$

A. ageratoides subsp. leiophyllus var. ovalifolius Kitamura タマバシロヨメナ $\quad 2 n=54$

A. sohayakiensis Koidzumi キシュウギク $2 n=18$

A. rugulosus var. shibukawaensis Kitamura et Murataシブカワシロギク $2 n=18$ 
A. dubius subsp. glabratus var. heterotrichus Kitamura ジョウシュウアズマギク２n=18

A. asparulus Nees $2 n=54$

A. spinosus Benth. $2 n=18$

A. oregonensis (Nutt.) Cronq. $2 n=18$

A. bcrnardinus Hall $2 n=36$

A. ontarionis Wieg. $2 n=40$

観 察 結 果

1) Felicia bergeriana O. Hoffin ルリヒナギク $2 n=18$. (Fig. 1) 线徭品

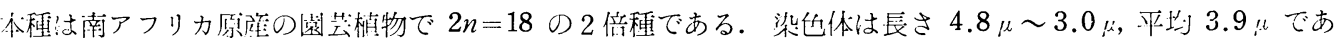
ク，1対は中部に，2刘は次端部に，他は次中部化着系点をもっている. 杉浦（1936）はF. amelloides Voss.

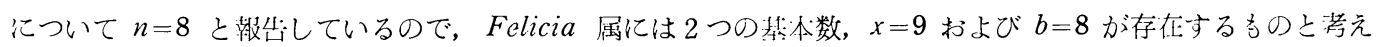
られる。

2) Erigoron spaciosus DC. ヒロハヒメジョオン $2 n=18$. (Fig. 2)

本種は北アメリカ原产の槛物であるが，用いた材料はデンマーク J.E. Ohlsens Enke Co. より邻入した種了. より得たものである.9刘の染色体のうち 4 対は次中部に, 他は次端部に着系点をもち, 核型は非刘称である.

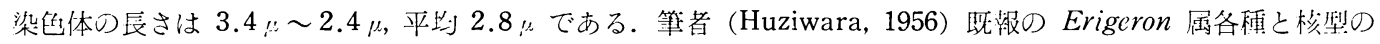
差は少ない。

3) Solidago minutissima (Makino) Kitamura イッスンキンカ $2 n=18$. (Fig. 3) 屋久舁窝浦岳産 本種は屋久島特㢈の植物で, きわめて小形の Solidago である.9 対の染色体のうち 4 対は中部に, 他は次中 部に着系点をもち, 核型は対称性が滈い. 染色体の長さは $4.0 \mu \sim 2.5 \mu$, 平均 $3.6 \mu$ である. 本種の核型各篻 者 (Huziwara, 1962 a) 睡派の Solidago 属植物の核型と類似する.

4) Boltonia asteroides L'Her. アメリカギク $2 n=27$. (Fig. 4) 栽培品

本種も北アメリカ原产の植物で, $2 n=27$ の 3 倍種である. 染色体は此較的小さく, 長さ $3.0 \mu \sim 1.8 \mu$, 平均 $2.0 \mu$ である. 次端部に着系点をもった 6 個を除けば,すずて次中部に着系点をもっている.

5) Rhynchospermum verticillatum Reinw. シュウブンソウ $2 n=18$. (Figs. 5, 16) 大陏府筌面座 本種の染色体数は $2 n=18$ で，荒野（1962）の㪕告と一致する. 最大の染色体 1 刘は短腕に二次くびれをる つ. 9 対の染色体のうち 2 刘は中部に, 他はすべて次中部に着系点をもち, 核型は全体として Aster 属に似て いる.

6) Aster taiwanensis var. lucens Kitamura テリハノギク $2 n=18$. (Fig. 6) 西表島浦内川産

本槛物は琉球産の Aster で, $2 n=18$ の 2 儅種である. 9 対の染色体のうち 4 対は中部に，他は次中部に着系 点をもち, 核型は刘称性が高い. 染色体はやや大形で, 長さ $7.2 \mu \sim 6.0 \mu$, 平均 $6.5 \mu$ である. 最大の 1 刘は 二次くびれをもった媣染体（L 2 E 染色体）である.

7) A. ageratoides subsp. leiophyllus var. ovalifolius Kitamura タマバシロヨメナ２n=54. (Fig.7) 鹿沼市石裂山産

本植物は $2 n=54$ の 倍種である. 27 対の染色体のうち10対は中部に, 他は次中部に着系点をもち, 対称の核 型を示す. 二次くびれをもった大形の仁染色体（L $2 \mathrm{E}$ 染色体）が 3 対認められるが最大の 1 対と他の 2 対とは全 長および着系点の位置において差異がある。このととは本植物が異質 6 倍性であるととを示すものである.

8) A. sohayakiensis Koidzumi キシュウギク $2 n=18$. (Figs. 8, 17) 和歌山県熊野川町産 本種の染色体は大形で, 長さ $9.6 \mu \sim 6.0 \mu$, 平均 $7.6 \mu$ である. 9 対の染色体のうち, 2 対は中部に, 他は 

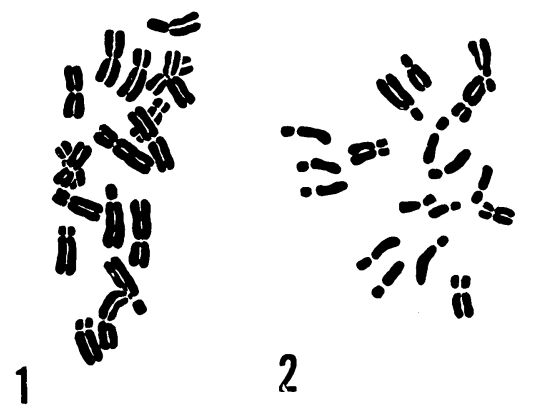

5

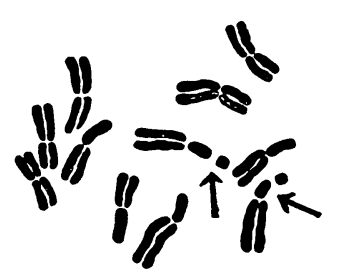

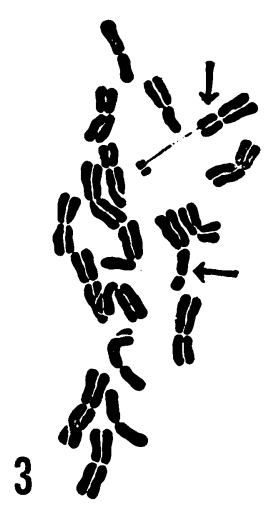
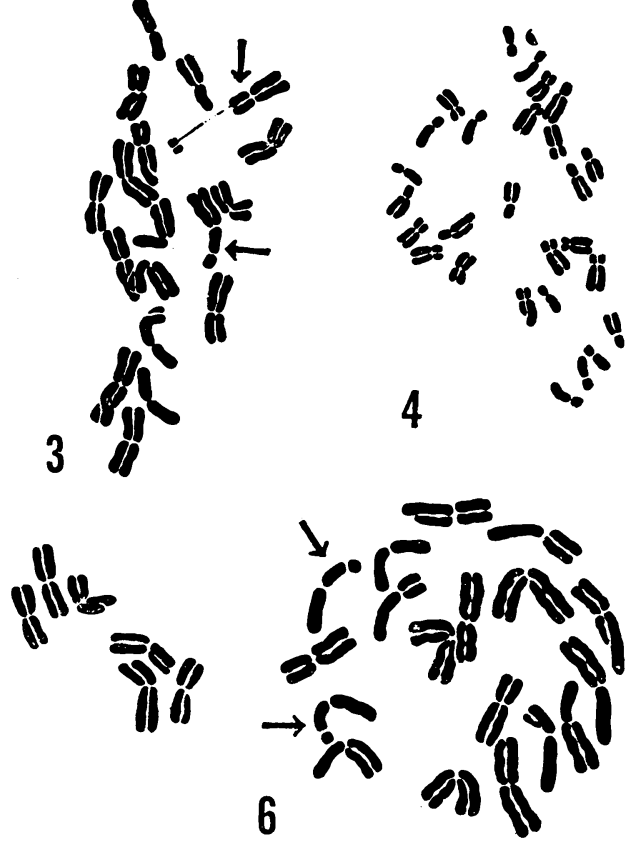

8

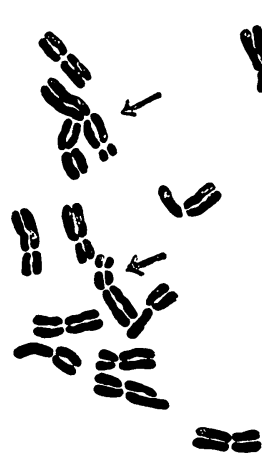

7
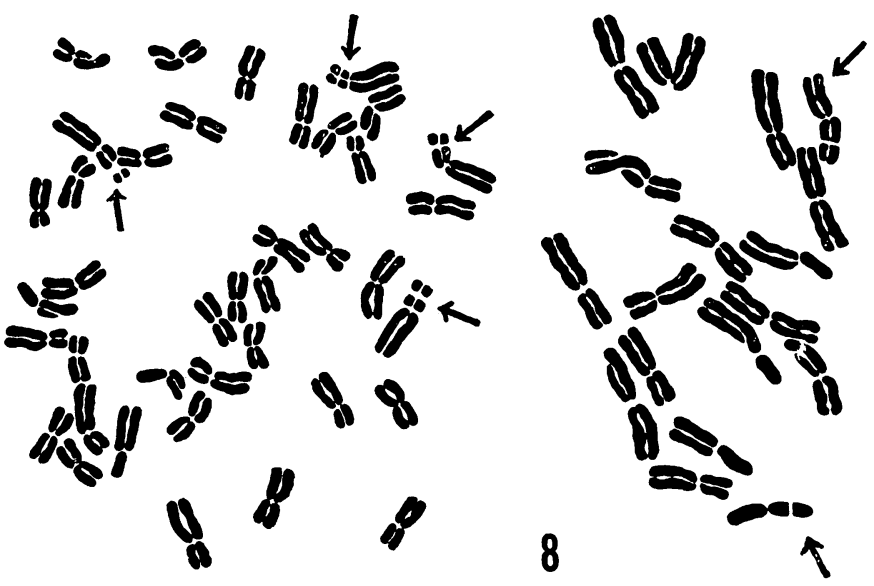

Figs. 1-8. Somatic chromosomes of Astereae. $\times 1800$.

1, Felicia bergeriana, $2 n=18 . \quad 2$, Erigeron speciosus, $2 n=18 . \quad 3$, Solidago minutissima, $2 n=18$. 4, Boltonia asteroides, $2 n=27$. 5, Rhynchospermum verticillatum, $2 n=18$. 6 , Aster taiwanensis var. lucens, $2 n=18 . \quad 7$, A. ageratoides subsp. leiophyllus var. ovalifolius, $2 n=54 . \quad 8$, A. soha yakiensis, $2 n=18$. Arrows indicate secondarily constricted chromosomes.

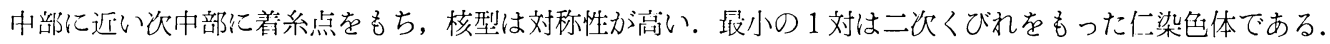

9) A. rugulosus var. shibukawaensis Kitamura et Murata シブカワシロギク $2 n=18$. (Figs. 9,

18）静网県滥川産

本植物注静岡県渋川にわいて発兄された新变種である（村田，1962）。体細胞染色体は18個あり，小山（1963） の筧定と一致する. 染色体は大形で長さ $9.0 \mu \sim 6.0 \mu$, 平均 $7.7 \mu$ である. 核型は全体として前種キシュウギ 

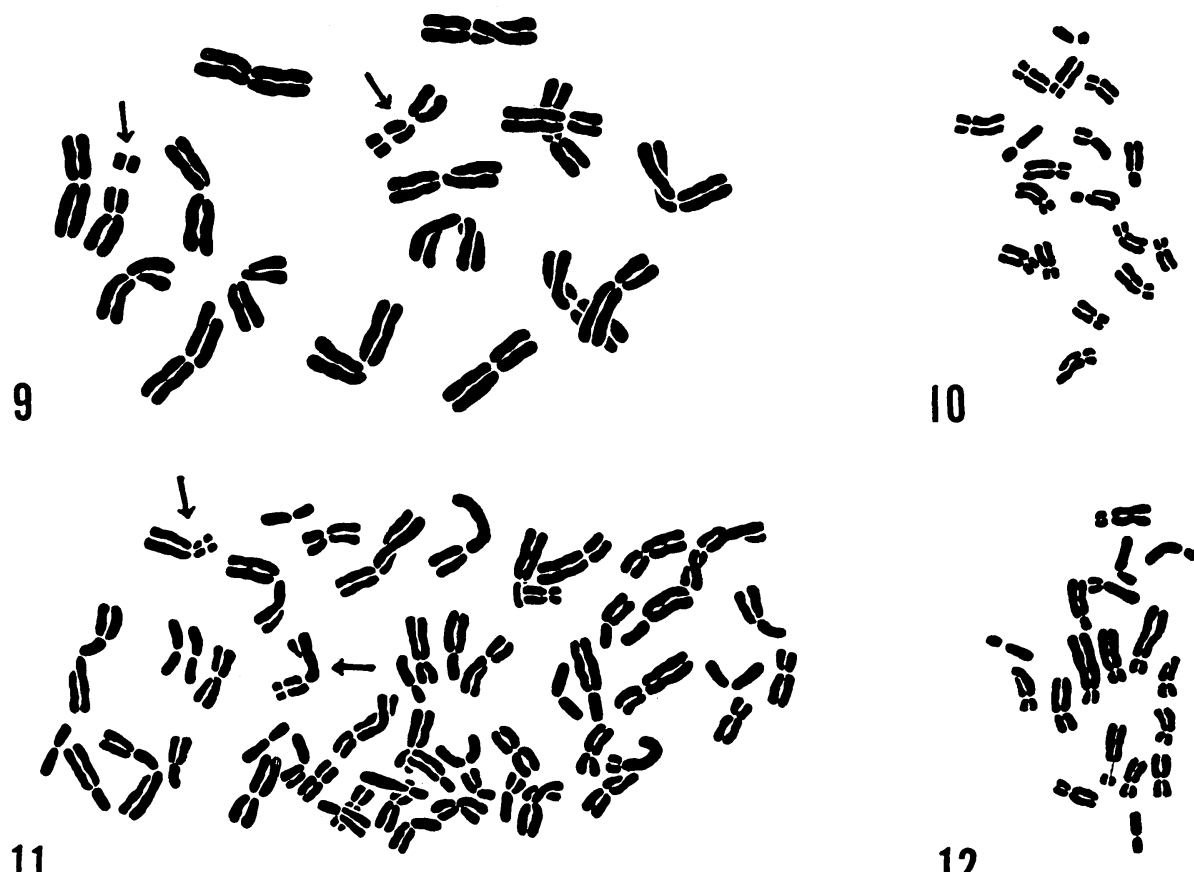

11

12
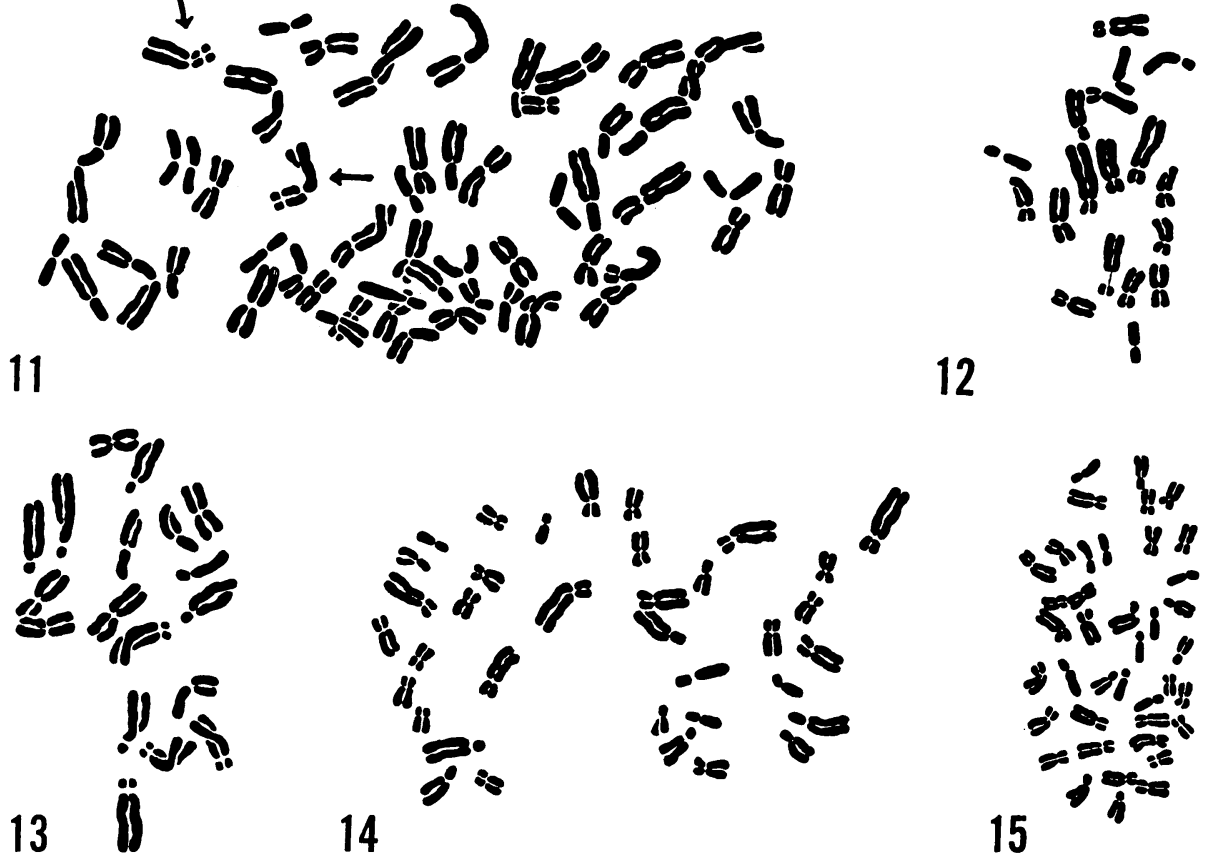

Figs. 9-15. Somatic chromosomes of Astereae. $\times 1800$.

9, Aster rugulosus var. shibukawaensis, $2 n=18 . \quad 10$, A. dubius subsp. glabratus var. heterotrichus, $2 n=18$. 11, A. asperulus, $2 n=54$. 12, A. spinosus, $2 n=18$. 13 , A. oregonensis, $2 n=18$. 14, A. bernardinus, $2 n=36$. $15, A$. ontarionis, $2 n=40$. Arrows indicate secondarily constricted chromosomes.

クに類似し，刘称性が离く，9刘の染色体のうち1刘は中部に他はすべて中部に近い次中部に着系点をもつ。

10) A. dubius subsp. glabratus var. heterotrichus Kitamura ジョウシュウアズマギク $2 n=18$

(Fig. 10) 群馬県至仏岳産

本植物も $2 n=18$ の 倍種であるが染色体はやや小形で, 長さ $4.0 \mu \sim 2.4 \mu$, 平均 $2.9 \mu$ である. 核型は非 対称で，筆者 (Huziwara, 1957 a) 既被の Alpigenia 節槛物と区別がない.

11) A. asperulus Nees $2 n=54$. (Fig. 11) インド産

本種はインド Darjeeling の G. Ghose \& Co. 上り輸入した種子より得たもので 6 倍体である. 27対の染色 


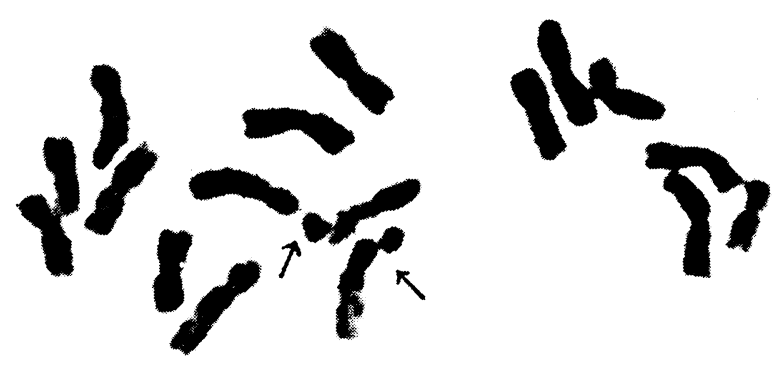

16
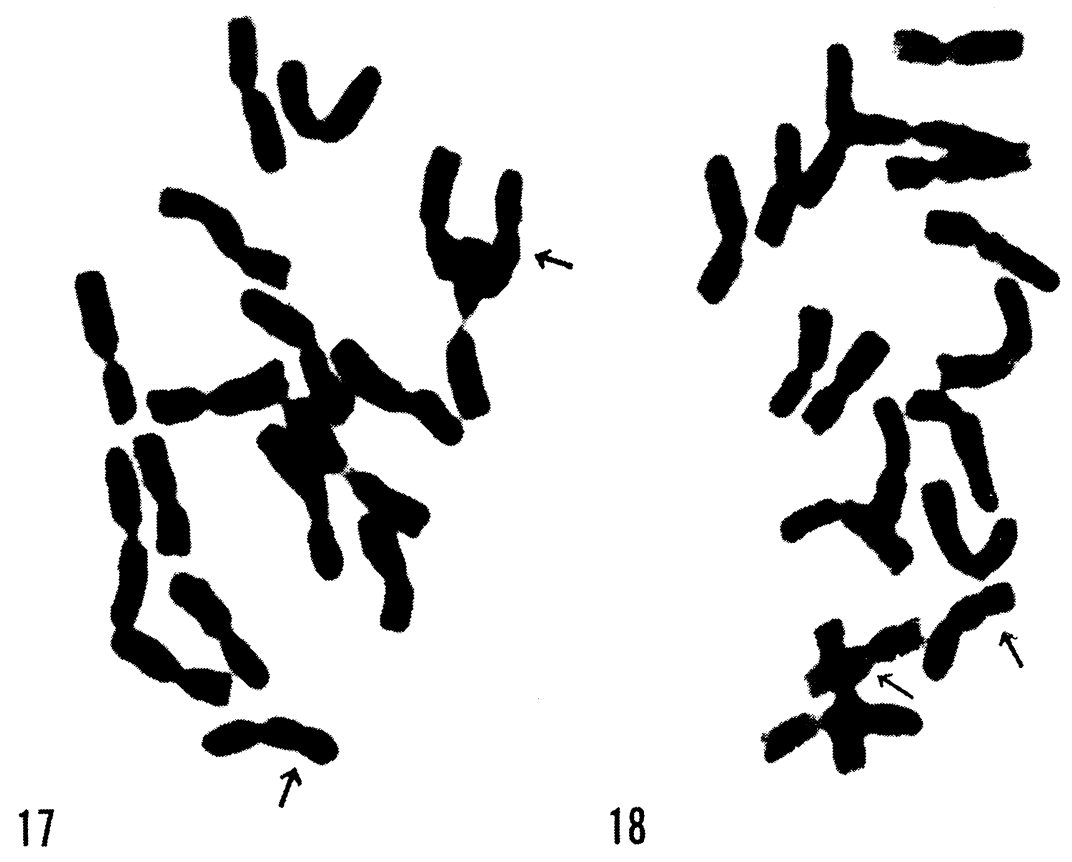

18

Figs. 16-18. Photomicrographs of somatic chromosomes of Astereae. $\times 2400$.

16, Rhynchospermum verticillatum, $2 n=18$. 17, Aster sohayakiensis, $2 n=18 . \quad 18$, A. rugulosus var. shibukawaensis, $2 n=18$. Arrows indicate secondarily constricted chromosomes.

体のうち 6 刘は中部に, 19刘は次中部に, 他は次端部に着系点をるち, 核型は対称性がやや高い。染色体は比較 ! 回”的大き, 長さ $8.4 \mu \sim 3.0 \mu$, 平均 $4.9 \mu$ である.

! 12) A. spinosus Benth. 2n=18. (Fig. 12) カリフォルニア El Centro 产

本種は北アメリカ産の枮物で, $2 n=18$ の 2 倍種である. 9 対の染色体のうち 6 対は次中部に, 他は次端部に

「着糸点をもつ. 染出体の長さは $4.8 \mu \sim 2.4 \mu$, 平圴 $3.3 \mu$ である. 
13) A. oregonensis (Nutt) Cronq. $2 n=18$. (Fig. 13) カリフォルニア Rancho Santa Ana 植物園産 本種も北アメリカ産の植物で $2 n=18$ の 2 倍体である. 9 体の染色体のうち， 1 対は中部に， 3 刘は次中部 に，他は次端部に着糸点をもち，核型は非刘称である。

14) A. bernardinus Hall $2 n=36$. (Fig. 14) カリフォルニア Claremont 應

本種は $2 n=36$ の 倍体である. 18対の染色体のうち11対は次中部に，他は次端部に着系点をもつ．染色体の 長さは $4.6 \mu \sim 1.6 \mu$, 平均 $2.5 \mu$ で, 最大染色体と最小染色体との長さの差が特に著しい.

15) A. ontarionis Wieg. $2 n=40$. (Fig. 15) Montréal 植物園産

本種も北アメリカ原産の植物で Quebec より Texas にわたり広く分布する．染色体数は $2 n=40$ で， 5 を 基本数とする 8 倍体と考えられる．20対のうち9 対は次中部に，他は次端部に着系点をもち，核型は非刘称で ある. 染色体はきわめて小さく，長さ $2.4 \mu \sim 1.4 \mu$, 平均 $1.9 \mu$ である.

Table 1. Data of somatic chromosomes of Astereae.

\begin{tabular}{|c|c|c|c|c|c|c|}
\hline \multirow{2}{*}{ Species } & \multirow{2}{*}{$2 n$} & \multicolumn{3}{|c|}{ Centromere* } & \multirow{2}{*}{$\begin{array}{l}\text { Average } \\
\text { Length } \\
\text { in } \mu\end{array}$} & \multirow{2}{*}{$\mathrm{TF} \% * *$} \\
\hline & & $\mathrm{m}$ & $\mathrm{sm}$ & st & & \\
\hline Felicia bergeriana & 18 & 2 & 12 & 4 & 3.9 & 36 \\
\hline Erigeron speciosus & 18 & - & 8 & 10 & 2.8 & 33 \\
\hline Solidago minutissima & 18 & 8 & 10 & - & 3.6 & 45 \\
\hline Boltonia asteroides & 27 & - & 21 & 6 & 2.0 & 32 \\
\hline Rhynchospermum verticillatum & 18 & 4 & 14 & - & 5.4 & 43 \\
\hline Aster taiwanensis var. lucens & 18 & 8 & 10 & - & 6.5 & 44 \\
\hline A. ageratoides subsp. leiophyllus var. ovalifolius & 54 & 20 & 34 & - & 4.9 & 43 \\
\hline A. sohayakiensis & 18 & 4 & 14 & - & 7.6 & 44 \\
\hline A. rugulosus var. shibukawaensis & 18 & 2 & 16 & - & 7.7 & 43 \\
\hline A. dubius subsp. glabratus var. heterotrichus & 18 & - & 10 & 8 & 2.9 & 31 \\
\hline A. asperulus & 54 & 12 & 38 & 4 & 4.9 & 41 \\
\hline A. spinosus & 18 & - & 12 & 6 & 3.3 & 33 \\
\hline A. oregonensis & 18 & 2 & 6 & 10 & 4.6 & 26 \\
\hline A. bernardinus & 36 & - & 22 & 14 & 2.5 & 30 \\
\hline A. ontarionis & 40 & - & 18 & 22 & 1.9 & 29 \\
\hline
\end{tabular}

* m, median; sm, submedian; st, subterminal.

** $\mathrm{TF} \%$ equals the ratio in percentage of the total sum of short arm lengths to the total sum of chromosome lengths.

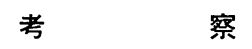

キク科ノコンギク族枯物のうち Felicia 属, Erigeron 属, Solidago 属, Boltonia 属, Rhynchospermum 属 各 1 種, Aster 属 6 種および 4 变種合計 15 種類について染色体数を決定し, 核型分析を行なった. 表 1 は上上の 観察絬果をまとめたものである.15種類のうち13種類の染色体数は今回初めて算定された.

染色体数についてはルリヒナギク, ヒロ八ヒメジョオン, イッスンキンカ, テリハノギク, キシュウギク, シ ブカワシロギク，ジョウシュウアズマギク，A. spinosus および A. oregonensis はいずれも $2 n=18$ の 2 倍 種, アメリカギクは 3 倍種, タマバシロヨメナおよび A. asperulus は 6 倍種, A. ontarionis は 8 倍䅞であ る.

染色体の大きさについてはテリハノギク, キシュウギクおよびシブカワシロギクが特に大きく, タマバシロヨ メナおよび A. asperulus がこれに次ぎ，アメリカギクおよび A. ontarionis は特に小さい. 
核型の対称性は TF％で示されシシュウブンソ ウ,テリハノギク, タマバシロヨメナ, キシュウギ クおよびシブカワシロギクにおいては中部または次 中部门着系点をもつ染色体が多く, それらの核型は 対称性が苫い $(\mathrm{TF} \%=44 \sim 43)$. 反刘に, ヒロ八ヒ メジョオン, アメリカギク, ショョウシュウアズマギ ク, A. spinosus, A. oregonensis, A. bernardinus および A. ontarionis は次端部に着系点をもつ染色 体が多々，核型は非対称である (TF\%=33〜26).

Aster 属のうち Alpigenia 節のものおよび北米 原産の種はいずれも小形の染色体をもち，非刘称の 核㤠を示し, 日本庰のものは此較的大形の染出体と 刘称の核型を示すととは嘅に都繁したが，今回の観 祭にわいても同じ結果を得た.

今回の郝㶵および筆者の彷来の報告において取扱 ったノコンギク属樵物は Aster, Gymnaster, $\mathrm{Ka}$ -

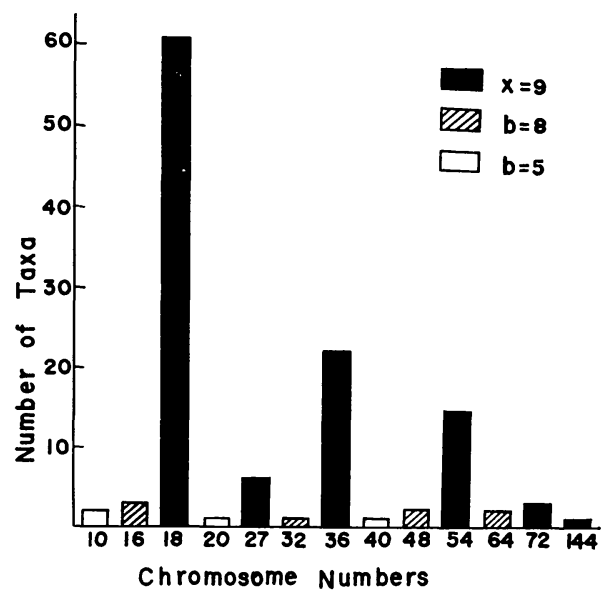

Fig. 19. Distribution of chromesome numbers in the euploid plants of the tribe Astereae.

limeris, Heteropappus, Erigeron, Solidago, Felicia, Bellis, Rhynchospermum, Boltonia, Lagenophora, Callistephus の12属にわたり，88種，20正種，18変種および 1 品種合計 127 種類である. このうち 119 種類が真 正倸数性を示し，それらの染色体数の分布は図 19 に示した通りである. 倍数レべルおよび染色体数により 2 倍 種 $(2 n=18,16,10) ， 3$ 倍種 $(2 n=27) ， 4$ 倍種 $(2 n=36,32,20), 6$ 㭞種 $(2 n=54,48), 8$ 倍種 $(2 n=72$, $64,40), 16$ 倍種 $(2 n=144)$ および異数種 $(2 n=68,63,49,46,38,19)$ を区別できる.

$2 n=1802$ 佔種一—エ゙ゴマナ, ゴマナ, タテヤマギク, モミジバタテヤマギク, ヒゴシオン, ヒメシオン, クルマギク, テリハノギク, 八コネギク, シロヨメナ, ナガバノシロヨメナ, イナカギク, コモノギク, ナ ガバシラヤマギク, シラヤマギク, サワシロギク, ヤマサワシロギク, シブカワシロギク, キシュウギク, オキナワギク, ダルマギク, イソノギク, カンヨメナ, アズマギク, ミヤマアズマギク, アポイアズマギ ク, ジョウシュウアズマギク, ウラギク, ミヤマヨメナ, ノシュンギク, シンジュギク, ユウガギク, チョ ウセンノギク, オオバヨメナ, ニイタカアズマギク, エゾムカショモギ, ハルジオン, ヒメムカショモギ, ヒロ八メショョオン, アキノキリンソウ, オオアキノキリンソウ, ミヤマアキノキリンソウ, アオヤギバナ, イッスンキンカ, ルリヒナギク, シュウブンソウ, ヒナギク, コケセンボンギク, エゾギク，ホウキギク，

Aster himalaicus, A. alpinus, A. ibericus, A. amellus, A. umbellatus, A. modestus, A.ptarmicoides, A. andersonii, A. alpigenia, A. oregonensis, A. spinosus

$2 n=16$ の 2 倍種—Aster puniceus, A. adscendens, A. occidentalis

$2 n=10$ の 2 倍種一一バリノギク, Aster exilis

$2 n=27$ の 3 倍種——ミヤマヨメナ, ノシュンギク, ヒメジョオン, アメリカギク, Aster alpinus, A. meritus

$2 n=36$ の 4 偕種一七ンボンギク，アキワギク，シロヨメナ，キントキシロヨメナ，ノコンギク，ハマコン ギク, コンギク, コマチギク，エゾノコンギク，チョクザキヨメナ，マヤサンコンギク，タニガワコンギ ク, ミヤマヨメナ, ヤナギノギグ, スナジ;ギク, アレノノギク, ペラペラヒメジョオン, ハダカアキノキ リンソウ, Aster altaicus, A. bernardinus, Taxon A I , Taxon A II

$2 n=32$ の 4 佁種—Aster ericoides

$2 n=20 の 4$ 倍種—Aster patens

$2 n=54$ の 6 倍種——シオ, オクエゾシオン, シロヨメナ, タマバシロヨメナ, コヨメナ, アレジギク, オ 
オアレジノギク，八マヨメナ，セイタカアキノキリンソウ, Erigeron compositus, Aster amellus, A. ibericus, A. amelloides, A. asperulus

$2 n=48$ の 6 倍種一一クゼンギク, Aster pilosus

$2 n=72$ の 8 倍種一一オユウガギク, ヤクシマコンギク, Aster macrophyllus

$2 n=64$ の 8 倍種—Aster chilensis, A. simplex

$2 n=40$ の 8 倍種—Aster ontarionis

$2 n=144$ の16倍種—チョウセンヨメナ

異数体一シロヨメナ $(2 n=19,38)$, キントキシロヨメナ $(2 n=38)$, イナカギク $(2 n=19)$, ユウゼンギク

$(2 n=49), \quad \exists メ ナ(2 n=63)$, Kalimeris yomena f. tubulosa $(2 n=68)$, Aster concinus $(2 n=46)$

以上のように，ノコンギク族における染色体数の範囲は広く，最大 $2 n=144$ から最小 $2 n=10$ におぶ. 倍 数種は合計 61 種類に達し， 2 倍種の種類とほぼ同数である.このことは本族植物における種の分化の上に倍数性 が重要なる役割を演じたてとを示すものである.

本族における真正倍数植物の大部分（90\%）が 9 を基本数としたものであることは，本族の一次的基本数は $x=9$ であって，乙の基本数から多くの倍数種が由来し，一方基本数の漸減によって二次的基本数の $b=8$ および $b=5$ が生じたと考えられる.すなわち, 基本数における変化もまた本族植物の進化の要因と見なされる.

ノコンギク族植物の倍数種は核型から見て異質倍数体と考えられるものが多く，自然における交雑と染色体倍 加てよって倍数種が成立した．また，てのようにして生じた異質倍数体の核型が長い年月の間に安定し，2倍種 の核型に類似したものとなっていることも興味がある.

ノコンギク族のアメリカ種と日本種とを比較するとき，Aster 属では染色体の大きさと核型の対称性とにおい て著しい差があり，アメリカ種は小形の染色体と非対称の核型を示すのに反し，日本種は大形の染色体と刘称の 核型を示す。染色体基本数もアジア種は 9 のみであるのに刘し，新世界種には $9 ， 8$ よび 5 のつが存在す る. Erigeron および Solidago にあっては染色体の大きさにおける差はないが，日本産のものはすべて 2 倍種 で,アメリカ種には高次の倍数種がある．乙れらのととから，ノコンギク族植物はアジアにおいて原始型を保持 し, アメリカ大陸において一層高度に進化したものと考えられる.

\section{要 約}

オキシキノリン法を用いてノコンギク族11種および 4 変種について染也体数を決定し，核型分析を行なった． 既厗の77種, 20 西種, 14 変種および 1 品種とあわせ合計 127 種類の本族植物について停数性と核型変化の傾向と を考察した.

終りに，材料植物の採集に協力いただいた田川基二 (京都大学)，中西 哲（神戸大学），鈴木賁雄（宇都宮中 央女子高校), Á. Löve (Montréal 大学), J. Kucyniak (Montréal 植物圆), R. M. Datta (Calcutta 大学), P. Raven (Stanford 大学) の諸博士に感謝する.

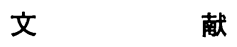

荒野久雄, 1962 邦産キク亜科植物の細胞学的研究, V. キク亜科の数属の核型分析と核学的考察. 染色体 5354: 1794-1810.

藤原悠紀雄, 1941 外国産 Aster 属植物の染色体数. 植物及動物 9: 75--76.

藤原悠紀雄, 1954 ヒナギク，エゾギクおよびアキノキリンソウの核型分析．染色体 $21:$ 773-776.

Huziwara, Y., 1957 a Karyotype analysis in some genera of Compositae. II. The karyotype of Japanese Aster species. Cytologia 22: 96-112.

Huziwara, Y., 1957 b Karyotype analysis in some genera of Compositae. III. The karyotype of the Aster ageratoides group. Amer. J. Bot. 44 : 783-790. 
Huziwara, Y., 1958 a Karyotype analysis in some genera of Compositae. IV. The karyotype within genera Gymnaster, Kalimeris and Heteropappus. Cytologia 23 : 33-45.

Huziwara, Y., $1958 \mathrm{~b}$ Karyotype analysis in some genera of Compositae. V. The chromosomes of American Aster species. Japan. J. Genet. 33: 129-137.

Huziwara, Y., 1958 c Karyotype analysis in some genera of Compositae. VI. The chromosomes of some Erigeron species. Caryologia $11: 158-164$.

Huziwara, Y., 1962 a Karyotype analysis in some genera of Compositae. VII. The chromosomes of Japanese Solidago species. Acta Phytotax. Geobot. 20 : 176-179.

Huziwara, Y., 1962 b Karyotype analysis in some genera of Compositae. VIII. Further studies on the chromosomes of Aster. Amer. J. Bot. 49: 116-119.

Huziwara, Y., 1962 c Karyotype analysis in some genera of Compositae. IX. Chromosomes of European Aster species. Bot. Mag., Tokyo 75 : 143-149.

小山博濕, 1963 シブカワシロギクの核型. 植物分類地理 19: 177.

村梐 源, 1962 植物分類雑記. 7. 植物分類地理 19:67-72.

Sugiura, T., 1936 Studies on the chromosome numbers in higher plants, with special reference to cytokinesis. I. Cytologia $7: 544-595$.

Tjio, J. H., and A. Levan, 1950 The use of oxyquinoline in chromosome analysis. Anal. Est. Exptl. de Aula dei 2 : 21-64. 